\title{
Drug-Facilitated Sexual Assault and Chemical Submission
}

\author{
Manuel Isorna Folgar ${ }^{1}$, Coromoto Souto Taboada ${ }^{1}$, Antonio Rial Boubeta ${ }^{2}$, \\ Antonio Alías ${ }^{3}$ and Kieran McCartan ${ }^{4}$ \\ ${ }^{1}$ University of Vigo, Spain ${ }^{2}$ University of Santiago de Compostela, Spain ${ }^{3}$ University of Almería, Spain \\ ${ }^{4}$ University of the West of England, United Kingdom
}

(Received on March 2, 2017; Accepted on April 10, 2017)

\begin{abstract}
In recent years, the use of psychoactive substances for sexual assault has taken on a greater role. The practice of sexual crimes associated with drug use is called Drug-Facilitated Sexual Assault (DFSA), while 'Chemical Submission' (CS) is used to include all type of crimes related to this activity. This paper reviews the epidemiology of this type of offenses, the main characteristics of the chemical substances consumed and the profiles of victims and aggressors. There have been also addressed principal signs of clinical suspicion to detect possible victims and the keys to the toxicology screening in case the victim presents evidences of being subject to chemical submission.
\end{abstract}

Key Words: Alcohol, drugs and sexuality, Chemical Submission, Drug-facilitated sexual assault, sexual offenses.

\section{Drogas facilitadoras del asalto sexual y Sumisión química}

RESUMEN: En los últimos años, el uso de sustancias psicoactivas relacionadas con las agresiones sexuales ha asumido un mayor protagonismo. La práctica de los delitos sexuales relacionados con el uso de drogas se denomina Drogas Facilitadoras del Asalto Sexual (DFSA por sus siglas en inglés), mientras que el término «Sumisión Química» (CS) se usa para incluir todo tipo de delitos relacionados con esta actividad. En este artículo se revisa la epidemiología de este tipo de asaltos, las características de las principales sustancias químicas consumidas, así como los perfiles de las víctimas y de los agresores. Asimismo, también se abordan los principales signos de sospecha clínica para detectar posibles víctimas así como las claves del examen toxicológico en caso de que la víctima presente síntomas de estar bajo el efecto de sustancias químicas.

Palabras Clave: Alcohol, drogas y sexualidad, Sumisión Química, Drogas facilitadoras del asalto sexual, delitos sexuales.

Correspondence: Manuel Isorna. Faculty of Education, University of Vigo. Email: isorna.catoira@gmail.com 
Substance use to dominate victim's will has been a recurrent practice throughout history, although it has been from the last decade of the twentieth century when an increase in the prevalence among crimes against sexual freedom and against property has appeared (Shbair, 2010). Drug taking is utilised in this type of practices with the aim of manipulating victims' will, what is known as Chemical Submission (CS). The term, first used by Poyen, Rodor, Jouve, Galland, Lots, and Jouglard (1982) refers to 'the substance administration to a person without his/her knowledge to cause him/her a change in the alertness, state of consciousness and judgment'. Victim's vulnerability is deliberately caused, making him/her be asleep or awake but under the control of the aggressor (Saint-Martin, Furet, O'Byrne, Bouyssy, Paintaud and Autret-Leca, 2006), to perpetrate a secondary damage as theft, signing documents and, principally, sexual assault.

The frequency of the phenomenon and the lack of specific revisions make necessary an updating of the data related to the prevalence, aggressor and victim's characteristics and profile, drugs most used and preventive measures to reduce the presence of these activities.

\section{METHOD}

It has been performed a bibliographical computerised research of articles published between 1990 and 2015. The information consulted was indexed into the electronic databases BVS-Psi, Cochrane Library, ERIC, ISOC and IME databases of the Spanish National Research Council (CSIC), Medline, Psicodoc, PsycInfo and Scopus to search for English and Spanish keywords of the field. Terminological exploration was focused on 'alcohol, drugs and sexuality', 'chemical submission', 'covert drug administration', 'drink spiking', 'Drug-Facilitated Sexual Assault', 'DFSA', 'Risky Sexual Behaviour (RSB)' and 'recreational drugs'.

The search has shown the need, highlighted in number of scientific studios and publications, of putting into practice an intervention on the field.

\section{HISTORICAL BACKGROUND}

In ancient times, drugs existed with a cultural and religious meaning associated with rites and ceremonies whose characteristics did not imply significant health damages. Human beings searched products to increase their sexual pleasure, resorting to various natural or synthetic substances, what have constituted an important aspect of the association between sexuality and drug use.

According what González et al. (2005) and Dueñas (1999) have pointed out, drugs may influence sexual activity in different ways affecting desire, sexual arousal and orgasm. While most of them present clear consequences on users' cognitive abilities increasing their sexual desire, as substances act as aphrodisiacs, some others reduce them. Nevertheless, the consumption of a substance that increases individual's libido does not always imply an improvement in the coitus or pleasure. Ignorance or underestimation of the health possible consequences is an element that prevails in those who use drugs for sexual satisfaction, being proved that effects of drugs on female and male sexuality are highly dangerous due to the 
possibility of causing irreversible and regrettable injuries for their users (Peugh and Belenko 2001; González et al., 2005).

Relationship between sex and drugs has been documented for hundreds of years (Martin, 2001). Love potions were used as sexual aid in ancient, classic and contemporary texts

principally when men pursued a woman (Bellis and Hughes, 2004), while the administration of opiates, magic mushrooms or other vegetable products without victim's knowledge has been practised in initiation rites of religious sects or tribes (Cruz-Landeira, Quintela and LópezRivadulla, 2008). Actually, those potions were often plants or other substances with psychoactive properties, usually provided without the individuals' knowledge, whose aim consisted in exciting or disorienting the person. The historical relationship in both genders between alcohol and sexual desinhibition is very well known (Bellis and Hughes, 2004; Martin, 2001), as well as the habit of encouraging someone to drink alcohol to increase probabilities of having sexual activity. At present, there are more substances potentially available than in any other time that can modify, directly or indirectly, the effects on sexual behaviour. Likewise, access to drugs is relatively easy at these times and their effects begin to be widely known especially due to the information posted on the Internet and offered by the Grow \& Smart shops, which also provide seeds and guidelines for cultivating some of them.

Currently, Drug-Facilitated Sexual Assault (DFSA), as a special form of CS, has a great healthsocial relevance due to its extensive relation with sexual victimisation. DFSA are substances provided to an individual without his/her consent or pressuring the person to consume more quantity than he/she had planned to leave him/her in a semiconscious state, and therefore, unable resist a sexual assault. Despite the fact that alcohol is presenting as the main DFSA (Butler and Welch, 2009), it is not the only one; cocaine, ketamine, methamphetamine, GHB, benzodiazepines and some intoxicative inhalants are also used (Slaughter, 2000). In the same way, there have been men who looked for sex or services of prostitutes reporting robberies (Lusthof, Lameijer and Zweipfenning, 2000; Trullàs, Nogué, Miró and Munné, 2003).

\section{DRUG-FACILITATED SEXUAL ASSAULT AND CHEMICAL SUBMISSION EPIDEMIOLOGY}

Several studies (Juhascik et al., 2007; Saint-Martin, Bouyssy, O'Byrne, 2007; Elliott, 2008) suggest that it is virtually impossible to know the real number of DFSA cases that occur, due to the difficulties of victims to remember what happened and the problems to detect substances in their body because of the short stay on it.

In France, a study conducted in Paris by Cheze, Duffort, Deveaux and Pepin (2005) from June 2003 to May 2004, registered 128 CS suspected cases, being analytically confirmed 23 of them, $18 \%$. Zolpidem and clonazepam were the substances most frequently identified, followed by bromazepam, nordazepam and midazolam. Rarely, other benzodiazepines and analogues were detected, and in about $50 \%$ of cases it was confirmed a victim's previous consumption of narcotics, drugs or illicit drugs. 
As recorded in the study conducted in Canada between 1993 and 2002 by McGregor, Ericksen, Ronald, Janssen, Van and Vliet and Schulzer (2004), from the total of 1,594 cases reported as sexual assaults, $246(15.4 \%)$ were classified as CS cases. The $95 \%$ of victims were women and the age group between 15 and 19 was the one that presented the highest risk of becoming victims. According to the authors, women under 20 are particularly vulnerable to this form of sexual assault, what makes necessary the creation of specific prevention programs targeting to this population group. The study also revealed a gradual increase in the diagnosed cases since 1999, due to:

a) The increase of information that victims can access because of the spread of the subject in the media.

b) The increase of the training of the health personnel, who used to diagnose as common assault CS cases.

c) The increase in the information that aggressors can obtain from Internet and the availability to access to drugs on the net.

In Australia during the period 2003-2004, CS cases were the $17.5 \%$ of the total number of sexual assault cases (Hurley, Parker and Wells, 2006). Victims were women in $95 \%$ of the cases and $77 \%$ of them admitted a voluntary consumption of alcohol ( $71 \%$ had consumed up to four units of standard drinks). Up to $46 \%$ of the victims recognised a voluntary consumption of psychoactive drugs, as benzodiazepines or antidepressants, and up to $25 \%$ admitted a recreational drug use. These data show, according to the authors, the infrequency of CS cases derived from an involuntary exposure to a chemical substance and the risk associated with the voluntary consumption of alcohol and drugs.

In the United Kingdom, Kershaw et al. (2001) evidenced that only $18 \%$ of victims of DFSA sexual assaults report the criminal action to the police, what necessarily implies the noninvestigation of the conduct in four out of five cases. This fact can have its origin in the lack of victimisation awareness of the attacked person who, in the $30 \%$ of the cases, does not consider that he/she has been victim of the commission of an illicit act. Furthermore, the number of rape incidents reported in a date in the charitable association The Roofie Foundation increased from 39 in 1990 to 935 in 2002, being reported to the police only one in eight cases (Beynon, McVeigh, McVeigh, Leavey and Bellis, 2008).

Epidemiological studies from other countries indicate that up to $17 \%$ of sexual assault cases could be classified as CS cases by involuntary exposure of the victim to a psychoactive substance, although a high percentage of victims admit a voluntary previous consumption of a substance (Cruz-Landeira et al., 2008).

In Norway a retrospective and descriptive study conducted by Hagemann et al. (2013) between 2003-2010 evidenced that $22 \%$ out of 264 cases of sexual assault that assisted at the Sexual Assault Center of the St. Olavs University Hospital in Trondheim were suspected of being proactive DFSA, although only five had findings of sedative drugs that were not accounted for by self-reported voluntary intake. Victim's profile was a young Western woman with an average age of 21 years old who in 22 occasions tested negative, 22 tested positive for ethanol only, while 13 tested positive for at least one drug other than ethanol.

(c) Psy, Soc, \& Educ, 2017, Vol. 9(2) 
In Spain it has been found a very little data in the field, possibly because it has had very little research on it, although currently it is being increased. Even though, the recorded data related with the prevalence of such criminal practices in the country shows that one out of three cases of sexual assault has its origin in the chemical submission (Navarro Escayola et al., 2013). The department of Seville of the National Institute of Toxicology and Forensic Sciences conducted one of the studies in this area in the period 2010-2012. When health personnel suspected of a possible CS case, a toxicological research was made to reveal the presence of alcohol or other psychoactive substances as well as the presence of semen. As conclusion of the obtained results, it was proved that more than half of the 73 studied cases presented negative results and only three of the summaries could be classified as clear cases of CS, because of the information from the victim, the facts and the results collected.

The Instituto de Medicina Legal of Alicante conducted a similar study, also retrospective and descriptive, in the period 2009-2012, where out of 179 cases of sexual assault detected, 19 of them had a high probability of being a possible DFSA case (10.6\%). Almost all of the victims were female (95\%), aged between 14-37 years old, and in most of the cases, the aggressor was a person $(74 \%)$ who was an acquaintance $(47 \%)$ of the victim. Most of the victims $(68 \%)$ admitted a previous voluntary alcohol consumption, pure or in combination with other psychoactive substances where cannabis and cocaine appeared more frequently. In the $47 \%$ of the cases there have been detected psychoactive substances that the victim had not voluntarily consumed and in $21 \%$ of them was found more than one substance According to Escayola and Vega (2013), drugs detected in an average time of 18.26 hours between the sexual assault and the sampling corresponded to cocaine $(26.3 \%)$, cannabinoids $(15.8 \%)$, benzodiazepines $(15.8 \%)$, alcohol (10.5\%) and amphetamines $(5.3 \%)$.

García-Caballero, Cruz-Landeira and Quintela (2014) conducted another descriptive and retrospective study in Spain related to cases of sexual assault associated with the consumption of chemical substances. The results of the study, based on the cases reported to the department of Madrid of the National Institute of Toxicology and Forensic Sciences during the years 2010, 2011 and 2012 found that, from the 306 cases of sexual assault or abuse submitted, 107 of them (34.96\%) presented criteria to be included as CS cases. Victim's profile was a young Spanish or Latin American woman with an average age of 25.9 years old, who admitted an alcohol consumption previously to the assault, and who suffers from a total or partial amnesia of the events. The toxicological analysis identified ethanol (61.7\%), drugs (40.2\%, mainly benzodiazepines) and illicit drugs (27.1\%, mainly cocaine), alone or in combination.

Likewise, the data described by García-Caballero does not substantially differ from which Xifró et al. (2015) made in Barcelona where, from the 114-suspected cases of chemical submission, $30.7 \%$ were positive. However, it was evidenced a change in the profile of the victim corresponding in the $65.7 \%$ of the cases with foreign women whose origin in $56.5 \%$ was Western European or North American.

Nevertheless, it should be noted that while the majority of attacks are carried out in urban areas and during the weekend (EMCDDA, 2008), belonging to communities with a high population index is not directly related with a higher probability of becoming in a DFAS victim. Data from 
the department of Madrid of the National Institute of Toxicology and Forensic Sciences evidenced that only $25.2 \%$ of the CS victims lived in the Autonomous Region of Madrid (whose population is $6.5 \mathrm{M}$ inhabitants), while the Basque Country and Galicia (with a population of $2.2 \mathrm{M}$ and $2.7 \mathrm{M}$ citizens), registered DFAS percentages of $20.6 \%$ and $15.0 \%$ respectively (García-Caballero, 2014). In the same way, it is important to note the nonexclusivity of women as the only sex victimised by chemical submission. Consequently, even sharing the main substances used to be victimised in both genders, alcohol and benzodiazepines, the objective pursued in each one is different. As a result, while women are intoxicated to be become in victims of sexual crimes, in the case of men they are drugged to be become in victims of crimes against the property (Bertomeu-Ruiz, 2013).

In a study of 1,179 registered cases conducted in USA, it was detected a high prevalence of alcohol positive cases, followed by cannabinoids, benzodiazepines, amphetamines and gammahydroxybutyrate (GHB). In a high percentage of cases, the victim had voluntarily consumed some substance and the offender, often an acquaintance of him/her, had taken advantage of this situation of weakness (ElSohly and Salamone, 1999).

In the United States, California has become into the first state to require students living in campus of the local universities to obtain a clear consent before having sex. The SB-967 law known as 'Yes means Yes' and signed by the California Governor Jerry Brown, defines consent to have sex as a voluntary agreement and not as a lack of resistance. The law states it must take place an 'affirmative, conscious, and voluntary agreement' to engage in sexual activity that 'can be revoked at any time', where the affirmative consent can be indicated by a verbal or non verbal 'yes'.

By law, a drunk, drugged, unconscious or asleep person may not have agreed to maintain sexual relations. It also states that consent can be transmitted by a 'yes' indicated verbally or non verbally, but the lack of resistance or protest cannot be taken as consent. The law requires universities that receive funds or assistance from the state to adopt the new law and to inform students about the difference between consensual sexual relations and sexual assault. It also notes 'silence or lack of resistance does not constitute consent', and specifies that a defendant cannot plead that he/she had assumed that the victim had given the consent when he/she was drunk, drugged, unconscious or asleep.

In some countries, such as New Zealand, rape with drugs is also considered when someone supplied substances to the victim and takes advantage of his/her semiconscious state to commit sexual acts (Jansen, 2004; New Zealand Herald, 2003). However, although most of the attention has focused on the use of illegal drugs in many countries, it is certain that the most detected substance in those cases of rape with drugs is alcohol (ElSohly and Salamone, 1999). 


\section{DRUGS, SEX AND GO PARTYING: A RECIPROCAL RELATION}

Go partying on weekends has a direct relationship for both men and women with sex and drugs. A lot of the scenarios, clubs or areas where people go out possess an aesthetic and cultural significance aimed at encouraging dates, interrelations and sex (Gilbert and Pearson, 2003; Calafat, Juan, Becoña, Mantecón and Ramón, 2009).

Undoubtedly, it is in the night-time fun context when most of the weekly consumption is produced, being common in this environment the polydrug (Observatorio Español sobre Drogas, 2013) which is linked to an increase on the number of sexual relations (Calafat et al., 2009). This use of substances is positively valued by young people as they consider them as facilitator instruments for sexual relations (Sumnall, Beynon, Conchie, Riley and Cole, 2007); in fact, in both genders opinion, alcohol in a party is fundamental to create the right atmosphere (Østergaard, 2007).

In many cases, drug consumption is associated with the search of different effects in a sexual relation. Regarding this aspect, the most positive valued substance is alcohol, because of its ability to facilitate intercourse, involvement in risky experiences and the increase of the arousal; while the second one for young people is cocaine as it increases the duration of the sexual relation (Calafat, Juan, Becoña and Mantecón, 2008).

There is a great variety of publications that analyse possible relation between the development of risky sexual behaviours and the consumption of a substance (Lau, Tsui and Lam, 2007; Roberts and Kennedy, 2006; Antón-Ruiz and Espada, 2009). Different studies as the conducted by So, Wong and De Leon (2005) found that $23.8 \%$ of young people had consumed alcohol before sex at some time in their life, and $6 \%$ of the total consumed the substance at the time of the study. They also found that the $4.4 \%$ of the people who consumed other drugs before the sexual activity and the $1.2 \%$ of who were using substances at that time evidencing, because of the study, significant relations between the development of risky sexual behaviours and the use of alcohol and other drugs. Likewise, Calafat et al. (2009) shown that a great number of people (76.6\%) had had sexual relations under the alcohol effects at least on one occasion, and $55.2 \%$ under the influence of illicit drugs.

In a more recent study of Calafat et al. (2013) with 700 young people, mainly from Germany and The United Kingdom who spend their holidays in the touristic areas of the Mediterranean coast, found that the $1.5 \%$ of the survey group reported having had sex against their will during this period. The sexual activity had been committed through physical force, duress or under the influence of alcohol or other drugs, finding no differences between men and women; that is, women were no more likely to have had sex against their will than heterosexual men. However, homosexual or bisexual men had even seven times more probabilities than men or women of any heterosexual sexuality of having sex against their will. The report suggests that it is possible that tourist drunk women can be seen as easy targets for both male tourists and local people of the area. 
In an intrasubject research Isorna, Fariña, Sierra and Vallejo-Medina (2015) show how under the influence of alcohol and other drugs almost all of the subjects present a significant change towards to a more favourable attitude to the use of DFSA and to the practise of risky sexual behaviours, being the results equally positive for both men and women.

While other studies have found significant differences between the development of risky behaviours and alcohol consumption before sexual activity, there are no significant connections in the case of the use of other drugs (Messiah, Bloch and Blin, 1998). Hingson et al. (2009) and Miller et al. (2007), agree that getting drunk is associated with several negative health behaviours. Going on a car driven by a drunk driver, car accidents, fights, smoking, risky sexual relations and the use of other drugs that individuals had no a prior intention of consuming are actions that increase the individual's level of intoxication and reduce his/her psycho-physical abilities.

There are other practices related to sexuality that also indicate risky behaviours. In this aspect, the study conducted by Calafat et al. (2009), emphasises that a $7.3 \%$ of people had paid for sex, with significant differences between men $(14.3 \%)$ and women $(0.9 \%)$, or had been paid for practising sex, again with significant differences between genders $(6.7 \%$ men, $0.4 \%$ women). However, there are no differences between males and females in having done a STD test $(14.3 \%$ of the sample) or having exchanged sex for drugs $(2.5 \%)$, whereas the study highlights the fact that younger people had been paid for having sexual activity more commonly than the elder ones.

By contrast, other studies argue that alcohol and other drugs are not the direct cause of later risky sexual behaviours (Taylor, Fulop and Green, 1999).

Generally, young people know and understand alcohol or drug effects on their sexual behaviour and, despite of this fact, they keep consuming them; however, for an increasing minority of people, the consumption of substances that alter their sexual behaviour is not a choice. Drugs are being used, secretly and in a growing way, to leave victims in a semiconscious state and unable to resist a sexual attack. The victim, commonly a young woman, declares being in a party, in a working dinner or in a friend's/acquaintance's house when she loses the consciousness after taking a drink. When the person recovers consciousness hours later he/she is confused, does not remember what happened during this time period and has the feeling of having had sexual relations with someone. The aggressor is a man and, in a high percentage of the cases, an acquaintance of the victim.

Detection of sexual assaults related with chemical submission becomes commonly difficult because of number of factors as the delay in searching for help from the victim, what facilitates the removal of the substance from the body, the low doses employed by the perpetrator and the confusion of the clinical situation with a voluntary alcohol poisoning (Cruz-Landeira et al., 2008). As amnesia is often a side effect of some of the drugs used for raping in a date, most of the victims never report criminal actions to the police (EMCDDA, 2002, 2003; Schwartz, Milteer and LeBeau, 2000) being difficult, as a result, evaluate the real impact of the DFSA (Saint-Martin et al., 2007; Elliott, 2008). Nevertheless, it is important to point that the reported 
cases are often related with the illicit administration of substances such as rophynol and other benzodiazepines, GHB and ketamine, mixed with drinks in the meeting places (Schwartz et al., 2000).

Studies evidenced that a significant percentage of the analysed young people had experienced risky practices during last year, being drugs significantly present. There are no significant differences between men and women in using condoms or taking measures for birth control, although there is some divergence in practising sex under the influence of alcohol and illicit drugs, where males present higher rates of practices than females (Calafat et al., 2009).

\section{DRUGS USED AS FACILITATED OF SEXUAL ASSAULT}

As Cruz-Landeira et al., (2008) and García-Repetto and Luisa-Soria (2011) have proved, substances regularly used to commit sexual assault present a series of characteristics that make them suitable for the intended purpose of the aggressor:

- They are easy to obtain: among them, ethanol, some psychotropic drugs and the illicit substances are the most commonly used. The most common means of acquisition for the substances, and necessary for the preparation techniques, are Internet and the Smart \& Grow Shops (Dumestre-Toulet and Verstraete, 1998).

- They have to be able to be activated at low doses to go unnoticed.

- They are short and fast-acting substances to facilitate control over the victim, to avoid his/her suspicion, and to prevent the changing circumstances can frustrate the aggressor's goals.

- They produce confused symptoms, which can induce health personnel to a confusion between victim's symptomatology and an alcoholic intoxication or an organic upset, causing a delay in the clinical diagnosis while the substance is being eliminated from the body.

- The administration to the victim has to be discreet, usually orally, and added to alcoholic beverages, which are the ideal vehicle to mask the taste and colour while enhancing the effects.

- Substances have to be difficult to detect by the victim, with no taste, odour or colour that can show their presence.

- Usually, they produce disinhibition, which is an advantage for the offender during the sexual assault because the victim can accept situations considered as intolerable for $\mathrm{him} / \mathrm{her}$ in a normal state of consciousness.

Finally, as reflected by Gaulier, Fonteau, Jouanel and Lachâtre (2004), substances have to produce the desired effects by the aggressor to have the victim under his control:

- Anterograde amnesia which possesses a very positive effect for the aggressor, due to it limits the information provided by the victim, the testimony, as well as it delays, hindering early biological sampling, or even sometimes impedes, the criminal accusation, especially when the amnesia is associated with a guilty or shameful feeling. This fact was evidenced in the Spanish study conducted by Xifró et al. (2015) where almost $90 \%$ of the victims showed anterograde amnesia, and two out of three, anterograde amnesia related with the sexual assault. 
- Sedation: to disrupt the ability of wakefulness, attention and response to aggression.

- Temporary and spatial disorientation, caused by the effects of the substances, and that often invalidates victim's testimony (Schwartz et al., 2000).

As the European Monitoring Centre for Drugs and Drug (2008) has established, alcohol is the substance which has a higher detection rate in DFAS cases, due to it collects the mentioned characteristics, reaching blood concentrations in victims up to $2 \mathrm{~g} / \mathrm{L}$. In like manner, the detection of the substance in victim's body can occur in an isolated way or in confluence with licit or illicit substances, mainly benzodiazepines, cocaine and cannabinoids.

\section{CANNABIS}

Cannabis has been linked to sexual behaviour for a long time and it is the most widely used recreational drug, commonly consumed before and after having sex, what makes possible to be used as a DFSA by the perpetrator. The substance is considered to increase sexual pleasure by stimulating relaxation and sense of touch (Buffum, Moser and Smith, 1988). However, the same relaxing properties linked with cannabis consumption can induce lower levels in the practice of safe sex (Poulin and Graham, 2001).

\section{COCAINE}

Cocaine has a long sexual history, and among recreational drug users, it has a reputation as an aphrodisiac (Gay, Newmeyer, Perry et al., 1982) with properties ranging from relaxation to a complete lack of inhibition. It is also well-considered as a substance that delays the orgasm and, therefore, prolongs coitus (Sumnall, Jerome and Cole, 2006). Some women especially highlight these positive effects, although the extension of the intercourse is sometimes seen as a disadvantage as it becomes uncomfortable. Likewise, drug effects can encourage to continue having sex, even if it is painful, what can result in genital abrasions increasing the risk of transmitting infections (Calafat, Juan, Becoña and Mantecón, 2008; Meneses, 2007).

\section{AMPHETAMINE AND METHAMPHETAMINE}

Methamphetamines are highly valued for their ability to increase sexual desire, and to intensify and prolong the orgasm (Buffum et al., 1988). Users of this substance, a stimulant highly associated with sexual activity, often have numerous sexual partners and unprotected sex more often than other drugs users (Rawson, Washton, Domier and Reiber, 2002).

\section{GHB (gamma-Hydroxybutyric acid)}

It is known by a large number of different names in the jargon such as 'Cherry Meth', 'Georgia Home Boy', 'Fantasy', 'Liquide Ecstasy', 'Soap', 'Scoop', 'Liquid E' and 'Liquid X', what sometimes can induce consumers to think they are not really taking GHB, especially in confused denominations such as Liquid Ecstasy. The GHB is a prescription drug that does not possess the believed effects of ecstasy, due to it is a muscle relaxant that produces feelings of euphoria and happiness and induces deep sleep. Its consumption causes so intense states of confusion that criminals use it to subdue their victims. There are also aphrodisiac properties 
attributed to the substance in many scenarios of nightlife, due to the euphoric effects and the increase of the sense of sexuality and the relaxation that it causes (Dillon and Degenhardt, 2001).

The main form of GHB administration is orally as a liquid. The substance is absorbed very quickly in the intestinal tract and reaches its maximum blood concentration after half an hour, although first symptoms appear 5-10 minutes after the consumption. The half-life of the drug in the body is short, about an hour in regular doses and with shorter effects in lower doses. The liver mainly produces the GHB elimination, only $1 \%$ is eliminated in the urine, also very fast; six hours after the consumption any blood concentration is detected and after ten hours, the drug no longer remains in the urine (Dueñas, 1998; Jones, Holmgren, Ahlner, 2012). Related with its use as DFSA, one of the biggest difficulties the substance presents is the rapid elimination from the body, what implies that it will not able to be detected in blood after 2-8 hours and in urine after 8-12 hours. Apparently, in patients with the liver function damaged the GHB is completely eliminated even sooner, after 4-6 hours from the consumption (Landabaso and Gutiérrez, 2003).

\section{MDMA or ECSTASY}

MDMA has become popularly known as 'ecstasy', shortened to 'E', 'X' or 'XTC', and other names as 'Roll', 'Adam' or 'Love Drug'. The substance has lately appeared, as well as other drugs, as an enhancer of sexual desire, and therefore used for DFSA purposes (Jones et al., 2012). Due to its effects, ecstasy can induce euphoria, feelings of empathy with other people and a decrease of the anxiety in the individual. Additionally, the substance causes loss of shyness, turns the individual into an extroverted person, causes a sensation of absolute happiness and hyperactivity, increases brain activity and resistance to fatigue as well as it increases the subject's sensation of physical strength. The drug was prior associated with the sensual properties than with the sexual ones and it became famous because of its capacity for stimulating consumers' tactile feelings and empathy, although not necessarily their sexuality (Measham, 2002). However, this image of ecstasy may be related to the emergence of many STDs, and consequently, to a careless practice of sex (Zuleand Desmond, 1999). Furthermore, the social image of this drug among young people, which is seen as a substance that 'increases sexual desire and arousal as well as it delays the orgasm', could have helped to spread the ecstasy consumption among youth; people are very interested in sex but little concerned about the transmission of STDs (Frosch, Shoptaw, Huber and Ling, 1996).

\section{ALCOHOL}

Alcohol is the substance most widely used to alter people's sexual behaviour, which is consumed by both genders to gain confidence when they interact with potential sexual partners (Abrahamson, 2004). Alcohol can be used as temporary substance to arouse sexual desire in individuals who otherwise would be less uninhibited. As other drugs, alcohol possesses properties that free from inhibitions and induce amnesia, what allows individuals to forget their actions, or their consequences, before, during and after sexual activity; when young people get drunk, their chances of practicing unprotected sex are doubled (Calafat et al., 2009). However, 
the licit condition of the substance and its advertising, although misleading, implies that beverage companies may exaggerate and attribute almost magical properties to it, as promise greater success in relations with the other gender.

Using alcohol as DFSA in a date implies that an individual encourages other people to drink more than they had planned, requires secretly for them larger amounts of alcohol or adds liquor and drinks to the existing beverages to get them enter into a state of chemical submission. Nevertheless, only alcohol can cause disinhibition, amnesic episodes and loss of consciousness, and, as most people drink alcohol when they relate to each other, it is difficult to distinguish what quantity has been covertly administered and what has been voluntarily consumed. Some authors argue that, when women look for alcoholic intoxication, they 'control the loss of control' (Measham, 2002); even though, sometimes, it is also common to observe rests of some other drugs (cocaine, ketamine, methamphetamine, GHB, benzodiazepines or some volatile inhalants) mixed with alcohol (Slaughter, 2000; Scott-Ham and Burton, 2006).

The possible and misleading relationship between alcohol and sex made through advertising has its origins in the transmitted message of the beverage companies, which have been trying to make people believe that drinking alcohol increases individual's sexual attractiveness and his/her social skills (Eurocare, 2001). However, while consuming small amounts of alcohol can increase person's confidence, consuming large amounts of the substance usually makes the subject unable to manage safe sex and vulnerable to develop unwanted sexual practices (Johnson and Stahl, 2004). Rawson, Washton, Domier and Reiber (2002) have detected that the male consumers of alcohol have significantly higher expectations than women about a potential increase in their sexual desire under the effects of the drug, and that they are more likely to have sex with someone other than their partner while they are under its influence.

\section{BENZODIAZEPINES AND HYPNOTICS}

This group is composed by benzodiazepines, flunitrazepam and lorazepam; hypnotics, zopiclone and zolpidem and neuroleptics, sedatives or anaesthetics what are used as DFSA once they are diluted into the victim's alcoholic beverage. The victim consumes the substances what cause on him/her somnolence and leave him/her in a total unconsciousness state (Beynon et al, 2008; Jones et al., 2012).

\section{JIMSON WEED}

Datura stramonium is a very common herbaceous plant that can exceed one meter in height. It flowers at the end of spring with white flowers with tubular calyx and prickly fruits of blackish seeds and can be obtained directly from the field, cultivating them or buying them in the Smart shops. The plant possesses alkaloids such as atropine, hyoscyamine and scopolamine what have been employed since ancient times for their allucinogenic effects and as magic potion in sexual rituals due to their properties. It has been evidenced that the consumption of mushrooms and hallucinogenic plants has become popular as drug of abuse with DFSA purposes (Schwartz et al., 2000). 


\section{KETAMINE}

Ketamine ('K', 'Special K', 'Kit Kat' or 'Cat Valium') is a dissociative anaesthetic developed in 1963 to replace phencyclidine (PCP) and currently used in human anaesthesia and veterinary medicine. It is a non-volatile anaesthetic agent marketed in 1965 by Parke \& Davis Laboratories as an anaesthetic with the names of Ketalin ${ }^{\circledR}$, Ketalar ${ }^{\circledR}$ and Ketina ${ }^{\circledR}$ for use in humans and Ketase ${ }^{\circledR}$ for animal use. Ketamine is presented as a translucent liquid and as a liposoluble derivative from the PCP. In the illicit market, ketamine can take many other forms as colourless liquid, white powder (white crystals), pills or capsules, so it may be used by different means of administration as intravenous, intramuscular (liquid), rectal (liquid), nasal (powder), pulmonary/ 'smoked' (powder) and oral (liquid, pill, capsule) (Royo-Isach, Magrané, Domingo and Cortés, 2004).

Ketamine is odourless and tasteless, so it can be added to beverages without being detected to induce amnesia. Because of these properties, the drug is sometimes given to victims, who do not suspect about its presence, and used in sexual assaults and as DFSA drug (Hidalgo, 2002; Jones et al., 2012).

\section{SCOPOLAMINE or BURUNDANGA}

Scopolamine is a highly toxic alkaloid that is obtained from some nightshades. It is used in medicine in minimum doses to treat dizziness, but the administration of doses higher than 330 micrograms causes delirium, psychosis, paralysis and death. Due to its narcotic properties, it is also used to induce sleep, by placing flowers under the pillow, and by criminals, as the drug makes the individual loses the will, to steal and to commit sexual assault under a state of chemical submission (Gonzales, 2010). However, in contrast with the alarming urban legends sometimes spread by the media, it has not been demonstrated the existence of a generalised use of burundanga (Xifró, Barbería and Pujol, 2014).

\section{AMYL NITRITE, 'POPPERS'}

The onomatopoeic name 'poppers' is derived from the noise that produces the ampoule that contains amyl nitrite when it is broken (Macher, 2010). This drug is directly inhaled, and after its consumption, a kind of gust on the head is experienced for two or three minutes. It is used to cause on the consumer a transient euphoria and to excite his/her sexual organs although it possesses side effects that some people note as a sensation of faint, excessive dizziness and weakness, especially when the consumer tries to make an effort. Amyl nitrite is a highly flammable substance that can cause severe headaches and irritate or even burn the skin if the drug is in contact with it. Despite the general thought, jars of poppers are sold as flavouring in some sex shops, private clubs or bars. However, this drug consumption makes difficult the erection in many cases and its use can derive in lethal consequences in case of ingestion with phosphodiesterase inhibitors (Viagra ${ }^{\circledR}$, Levitra ${ }^{\circledR}$ or Cialis $\left.{ }^{\circledR}\right)$ (Macher, 2010).

In foreplay, nitrates have a disinhibition effect, contribute to muscle relaxation, decrease pain perception and therefore facilitate anal penetration. This fact has probably been what has 
helped that its use is more common among the homosexual collective, though not exclusively. Additionally, once the sphincter is relaxed due to the vasodilation, the risk of infection during sexual intercourse, especially in the anal type, is increased (Romanelli, Smith, Thornton and Pomeroy, 2004).

Likewise, when poppers are inhaled before orgasm, the consumer may experience a sense of euphoria, disinhibition in movements and vocalisations as well as a perception that the orgasm continues and intensifies. In addition, the individual can get to see patterns of different shapes and colours that change rapidly.

\section{CLINICAL EXAMINATION}

An appropriate clinical suspicion in cases of sexual assault corresponding with the previously explained pattern is essential for the detection of the criminal action. The delay in the suspicion substantially limits the possibility of success, due to the quick elimination of the substances from this biological environment and the low doses employed by the perpetrator. All health personnel of the emergency services that assist victims of such aggression should know the action protocol for these cases (Bernard, 2008; Vega, 2012; Xifró et al., 2013). This fact will be particularly important in the physical exam and in the detailed description of all the findings, as well as in the moment of taking and storing samples of biological material (urine, blood and hair) which, in case of being necessary or requested by a competent authority, can be subjected to toxicological and biological studies. In these cases, the conservation of the examined person's clothing will be very useful, due to it can provide evidences to the investigation. It is recommended to sample both blood and urine within the following 48 hours from the facts and to obtain a urine sample within 48 and 168 hours ( 7 days). If the person is examined after 7 days from the sexual assault, blood and urine samples are not available; therefore, it is recommended to obtain a sample of hair at the time of the first examination and a second one six weeks after (Xifró et al., 2013).

At the time of the clinical examination in the emergency services, the symptomatology in the victim, who usually presents neurological symptoms, is not specific. The anamnesis is complicated due to the anxiety, the amnesia and because of the dazed state in which the individual is. Some of the victim's statements are: 'I do not remember what happened', 'I feel like I was drugged', 'I feel that something happened to me', 'I was drinking and I started to feel dizzy, more than usual', 'I got a drink and do not remember anything else', 'I woke up naked', 'I woke up with the wrong clothes on', 'someone put a rag in my mouth', 'I woke up in a place I did not know', 'I woke up with a stranger' or even 'when I woke up someone was raping me'.

As a result, health personnel who treat these victims should know principle characteristics of the situation to offer them a suitable attention. The most characteristic clinical manifestations that appear on victims are partial or total amnesia, nystagmus, red eyes, alcoholic breath, dysmetria, alterations in language, altered state of consciousness, mydriasis, ataxia and disorientation. The health personnel work is crucial to get a quick and appropriate obtaining of the necessary biological samples for toxicological analysis in blood, urine and hair, and for 
their sending, guaranteeing the chain of custody, to a laboratory specialised in this type of analysis.

Women's physical examination includes examining the breasts, inspection of the vulva, labia majora and minora, description of any traumatic injuries and the description of the hymen or its rests, stating its shape, the characteristics of the edges and any recent or old traumatic injuries using a clock face analogy (Montoya et al., 2004).

In all of the cases, it should be taken into consideration that victims may interpret questions about their voluntary consumption of the substance as a questioning to their credibility. In the case health personnel consider it appropiate, they will explain to the subject that analysis in blood and urine detect the presence of alcohol and drugs, what is needed to clarify the substances voluntarily consumed and involuntarily administered (Xifró et al., 2013).

\section{CONCLUSION}

The outlook that emerges from the whole of Spanish publications regarding CS in general, and chemical submission with sexual purpose in particular, is similar to the neighbouring countries, where it is estimated that up to $17 \%$ of sexual assaults could be classified as CS cases due to the involuntary exposure of the victim to a psychoactive substance. In contrast to the alarming urban legends, sometimes created by media, neither the existence of a widespread use of any particular substance nor a particular use of the called date-rape drugs as the GHB or the burundanga has been demonstrated (Cruz-Landeira et al., 2008).

The available data to date suggest that CS is still a relatively rare phenomenon with a stable prevalence (García-Repetto, 2014) and with its own criminological characteristics (Beynon et al., 2008). However, the commission of a crime on a victim whose capabilities are diminished by voluntary or involuntary consumption of alcohol, drugs or psychotropic drugs, has emerged as a public health problem that people should know (Frison, Favretto, Tedeschi and Ferrara, 2003). In any case, suspicion of a CS case should result in a forensic protocol of action, and regarding this aspect, the Spanish situation has substantially improved in the recent years.

DFSA reflects some of the changes our society has been living recently and the key to explain new patterns of drug use, as well as problems that result from its consumption in young people (Becoña et al., 2011). This popular fun context, called "Modelo de diversión hegemónico" (Hegemonic Model of Entertainment, Calafat et al., 2004), first arose in the touristic areas of Spain and quickly spread to the other parts of the country. It is characterised by consuming significant amounts of alcohol and drugs and by practising sex with multiple partners (Bellis, Hale, Bennet, Chaves and Kilfoyle, 2000). Despite the fact that this way of nightlife is not a relatively recent phenomenon, its relevance cannot be omitted as the society is experiencing some of the negative consequences associated with it as traffic accidents, unwanted pregnancies, increase in sexually transmitted diseases and, of course, chemical submission. Because of this, it is needed to develop specific preventive interventions in this field due to the notable negative consequences it presents (Calafat, Juan and Duch, 2009). 
Studies as the conducted by McGregor, Ericksen, Ronald, Janssen, Van Vliet, Schulzer (2004) and Elliott (2008) reflect the need to work on prevention and information with potential victims, such as women under 20 , who are particularly vulnerable to this form of sexual assault. Because of this, it is fundamental to create specific prevention programs targeting this population group and also to train health personnel, due to an appropriate and early sampling is a key factor in confirming the diagnosis. It cannot be forgotten that $100 \%$ of cases of sexual violence, and at least $2 / 3$ of the remaining ones, present considerable emotional reactions, especially fear, depression and anger that lead victims to present significant changes in their lifestyles (Shapland, 1990).

However, due to the difficulties previously mentioned not all the suspected cases of CS will be analytically confirmed, as the toxicology cannot discern between the voluntary and the involuntary consumption of a drug, especially when the substance is regularly consumed by the victim.

\section{REFERENCES}

Antón-Ruiz, F., Espada, J. (2009). Consumo de sustancias y conductas sexuales de riesgo para la transmisión del VIH en una muestra de estudiantes universitarios. Anales de psicología, 25(2), 344-350.

Becoña, E.; López-Durán, A., Fernández, E., Martínez, U., Osorio, J., Fraga, J.; Arrojo, M., López Crecente, F., Domínguez, N. (2011). Borracheras, conducción de vehículos y relaciones sexuales en jóvenes consumidores de cocaína y éxtasis. Adicciones, 23(3), 205-218.

Bellis, M. A., Hughes, K. (2004). Pociones sexuales. Relación entre alcohol, drogas y sexo. Adicciones, 16(4), 249-258.

Bellis, M. A., Hale, G., Bennet, L. A., Chaves, M., Kilfoyle, M. (2000). Ibiza uncovered: Changes in substance use and sexual behaviour among young people visiting an international night-life resort. International Journal of Drug Policy, 11, 235-244.

Bernard, M. (2008). Current clinical aspects of drug-facilitated sexual assaults in sexually abused victims examined in a forensic emergency unit. Therapeutic Drug Monitoring, 30, 218-224.

Bertomeu-Ruiz, A., Arroyo-Fernández, A.; Pujol-Robinat, A. et al. (2013) Sumisión química y robos en serie, Revista Española de Medicina Legal. 39(1), 40-41

Beynon, C. M., McVeigh, C., McVeigh, J., Leavey, C., Bellis, M. A. (2008). The involvement of drugs and alcohol in drug facilitated sexual assault. Trauma Violence Abuse, 9, 178188.

Buffum, J., Moser, C., Smith, D. (1988). Street drugs and sexual function. In Sitsen JMA. Handbook of Sexology. Volume VI. The pharmacology and endocrinology of sexual function. Amsterdam: Elsevier.

Butler, B., Welch, J. (2009). Drug-facilitated sexual assault. Canadian Medical Association Journal, 180(5), 493-494.doi: 10.1503/cmaj.090006

Calafat, A., Fernandez, C., Juan, M., Anttila, A., Bellis, M., Bohrn, K., Zavatti, P. (2004). Cultural mediators in hegemonic night life. Palma de Mallorca: Irefrea. 
Calafat, A., Hughes, K., Blay, N., Bellis, M., Mendes, F., Juan, M., Lazarov et al., (2013). Sexual Harassment among Young Tourists Visiting Mediterranean Resorts. Archives of Sexual Behaviour, 42, 603-613. DOI 10.1007/s10508-012-9979-6.

Calafat, A., Juan, M., Duch, M. A. (2009). Intervenciones preventivas en contextos recreativos nocturnos: revisión. Adicciones, 21, 387-414.

Calafat, A., Juan, M., Becoña, E., Mantecón, A. (2008). Qué drogas se prefieren para las relaciones sexuales en contextos recreativos. Adicciones, 20, 37-47

Calafat, A., Juan, M., Becoña, E., Mantecón, A., Ramón, A. (2009). Sexualidad de riesgo y consumo de drogas en el contexto recreativo. Una perspectiva de género. Psicothema, 21(2), 227-233.

Cheze, M., Duffort, G., Deveaux, M., Pepin G. (2005). Hair analysis by liquid chromatography-tandem mass spectrometry in toxicological investigation of drugfacilitated crimes: report of 128 cases over the period June 2003-May 2004 in metropolitan Paris. Forensic Science International, 153, 3-10.

Cruz-Landeira, A., Quintela-Jorge, O., López-Rivadulla, M. (2008). Sumisión química: epidemiología y claves para su diagnóstico. Medicina Clínica (Barc). 131(20), 783-789.

Dillon, P., Degenhardt, L. (2001). Ketamine and GHB: new trends in club drug use?. Journal of Substance Use, 6(1), 11-15. doi/pdf/10.1080/146598901750132045.

Dueñas A. (1998). Ácido gamma-hidroxibutírico o éxtasis líquido ¿la intoxicación que viene? Medicina Clínica, 111, 24-26.

Dueñas, A. (1999). Intoxicaciones agudas en medicina de urgencia y cuidados críticos. Barcelona: Masson.

Dumestre-Toulet, V., Verstraete, A. (1998) Hallucinogènes et internet ou le cyber space psychédélique. Toxicorama, 10, 98-105.

Elliott, S. (2008). Drug-facilitated sexual assault: educating women about the risks. Nursing for Women's Health, 12, 30-37.

ElSohly, M., Salamone, S. (1999). Prevalence of drugs used in cases of alleged sexual assault. Journal of Analytical Toxicology, 23, 141-146.

European Monitoring Centre for Drugs and Drug (EMCDDA) (2002). Report on the risk assessment of GHB in the framework of the joint action on new synthetic drugs. Luxembourg: Office for Official Publications of the European Union.

European Monitoring Centre for Drugs and Drug (EMCDDA) (2003). Annual Report 2003: The state of the drugs problem in the European Union and Norway. Lisbon: EMCDDA.

European Monitoring Centre for Drugs and Drug (EMCDDA) (2008). Sexual assaults facilitated by drugs or alcohol. Lisbon: EMCDDA

Escayola, N., Vega, C. (2013). Agresiones sexuales facilitadas por sustancias psicoactivas, detectadas en el instituto de medicina legal de Alicante en el cuatrienio 2009-2012. Gaceta Internacional de Ciencias Forenses, (8), 8-15.

Eurocare (2001). Marketing alcohol to young people. StIves: Eurocare.

Frison, G., Favretto, D., Tedeschi, L., Ferrara S. D. (2003). Detection of thiopental and pentobarbital in head and pubis hair in a case of drug-facilitated sexual assault. Forensic Science International, 133, 171-4.

Frosch, D., Shoptaw, S., Huber, A., Ling, W. (1996). Sexual HIV risk among gay and bisexual male methamphetamine abusers. Journal of Substance Abuse Treatment, 13, 483-486. 
García-Caballero, C., Cruz-Landeira, A., Quintela, O. (2014). Sumisión química en casos de presuntos delitos contra la libertad sexual analizados en el Instituto Nacional de Toxicología y Ciencias Forenses (Departamento de Madrid) durante los años 2010, 2011 y 2012. Revista Española de Medicina Legal, 40(1),11-18.

García-Repetto, R., Soria, M. L. (2014). Consideraciones toxicológicas sobre supuestos casos de sumisión química en delitos de índole sexual en el sur de España entre los años 20102012. Revista Española de Medicina Legal, 40(1), 4-10.

García-Repetto, R., Soria, M. L. (2011). Drug-facilitated crime: A challenge for the forensic toxicologist. Revista Española de Medicina Legal, 37(3), 105-112.

Gaulier, J., Fonteau, F., Jouanel, E., Lachâtre, G. (2004). Les substances de la soumission chimique: aspects pharmacologiques et analytiques. Annales de Biologie Clinique, 62, 529-538.

Gay, G. R., Newmeyer, J. A., Perry, M. et al. (1982). Love and haight: The sensuous hippy revisited. Drug/sex practices in San Francisco, 1980-81. Journal of Psychoactive Drugs; $14,111-123$.

Gilbert, J. \& Pearson, E. (2003). Cultura y políticas de la música dance. Disco, hip-hop, house, techno, drum'n'bass y garage. Barcelona: Paidós.

Gonzales, P. (2010). La Escopolamina. Revista de Química PUCP, 24(1),11-13.

González, T. et al., (2005). Drogas y sexualidad: grandes enemigos. Revista Cubana de Medicina General Integral, 21, 5-6.

Hagemann, C., Helland, A., Spigset, O., Espnes, K., Ormstad, K., Schei, B. (2013). Ethanol and drug findings in women consulting a Sexual Assault Center - Associations with clinical characteristics and suspicions of drug-facilitated sexual assault. Journal of Forensic and Legal Medicine, 20(6),777-784.

Hurley, M., Parker H., Wells D. (2006). The epidemiology of drug facilitated sexual assault. Journal of Clinical Forensic Medicine, 13, 181-185.

Isorna, M., Fariña, F., Sierra, J. C., Vallejo-Medina, P. (2015). Binge drinking: conductas sexuales de riesgo y drogas facilitadoras del asalto sexual en jóvenes españoles. Suma Psicológica, 22(1), 1-8.

Jansen, K. (2004). Ecstasy (MDMA), other club drugs and drug-facilitated sexual assault. Proceedings. Club Health 2004, April 18th-20th 2004, Melbourne, Australia.

Johnson, T. J., Stahl, C. (2004). Sexual experiences associated with participation in drinking games. The Journal of General Psychology, 131, 304-320.

Jones, A., Holmgren, A., Ahlner, J. (2012). Toxicological analysis of blood and urine samples from female victims of alleged sexual assault. Clinical Toxicology, 50(7), 555561.doi:10.3109/15563650.2012.702217.

Juhascik, M., Negrusz, A., Faugno, D., Ledray, L., Greene, P., Lindner, A., Haner, B. \& Gaensslen, R. E. (2007). An estimate of the proportion of drug facilitation of sexual assault in four U. S. localities. Journal of Forensic Sciences, 2007; 52:1396-1400.

Kershaw, C., Chivite-Mathews, N., Thomas, C., Aust, R. (2001). The 2001 British Crime Survey: First Results, England and Wales. Home Office Statistical Bulletin 18/01. London: Home Office.

Landabaso, M., Gutiérrez, M. (2003). Aproximación terapéutica al uso y abuso de drogas recreativas. Adicciones, 15, (2), 347-351. 
Lusthof, K. J., Lameijer, W., Zweipfenning, P. (2000). Use of clonidine for chemical submission. Journal of Toxicology. Clinical Toxicology, 38, 329-332.

Macher, A. M. (2010). Abuse of club drugs volatile nitrites. American Jails, 24(4), 63-70.

Martin, L. (2001). Alcohol, sex and gender in late medieval and early modern Europe. Palgrave: New York.

McGregor, M., Ericksen, J., Ronald, L., Janssen, P., Van Vliet, A., Schulzer, M. (2004). Rising incidence of hospital reported drug-facilitated sexual assault in a large urban community in Canada. Retrospective population-based study. Canadian Journal of Public Health, $95,441-445$.

Measham, F. (2002). Doing gender-doing drugs. Conceptualising the gendering of drug cultures. Contemporary Drug Problems, 29, 335-373.

Meneses, C. (2007). Consecuencias del uso de cocaína en las personas que ejercen la prostitución. Gaceta sanitaria, 21(3), 191-196.

Messiah, A., Bloch, J., Blin, P. (1998). Alcohol or drug use and compliance with the safe sex Guidelines for STD/HIV Infection: results from ACSF among heterosexuals. Sexually Transmitted Diseases, 25 (3), 119-124.

Montoya D. et al., (2004). Peritaje médico legal en delitos sexuales: una pauta práctica para su trabajo. Revista Chilena de Obstetricia y Ginecología, 69(1).

Navarro Escayola, E., Vega Vega, C. (2013). Agresiones sexuales facilitadas por drogas psicoactivas, detectadas en el Instituto de Medicina Legal de Alicante en el cuatrienio 2009-2012. Gaceta Internacional de Ciencias Forenses, 8, 8-15

New Zealand Herald (2003). Restauranteur found to have sexually violated young men. 22nd November 2003.

Observatorio Español de la Droga y las Toxicomanías (2013). Informe 2013. Alcohol, tabaco y drogas ilegales en España. Madrid: Ministerio de Sanidad, Servicios Sociales e Igualdad.

Østergaard, J. (2007). Mind the gender gap! When boys and girls get drunk at a party. Nordic Studies on Alcohol and Drugs, 24, 127-145.

Peugh, J., Belenko, S. (2001). Alcohol, Drugs and Sexual Function: A Review. Journal of Psychoactive Drugs, 33(3), 223-232.DOI: 10.1080 / 02791072.2001.10400569.

Poulin, C., Graham, L. (2001). The association between substance use and unplanned sexual intercourse and other sexual behaviours among adolescents. Addiction, 96, 607-621.

Poyen, B., Rodor, F., Jouve, M. H., Galland, M., Lots, R., Jouglard, J. (1982). Amnésient troubles comportementaux d'apparence délictuelle sur venue après ingestion de benzodiazépines. Thérapie, 37, 675-678.

Rawson, R., Washton, A., Domier, C., Reiber, C. (2002). Drugs and sexual effects: role of drug type and gender. Journal of Substance Abuse Treatment, 22, 103-108.

Roberts, S. T., Kennedy, B. (2006). Why are young college women not using condoms? Their perceived risk, drug use, and developmental vulnerability may provide important clues to sexual risk. Archives of Psychiatric Nursing, 20(1), 32-40.

Romanelli, F., Smith, K., Thornton, A., Pomeroy, C. (2004). Poppers: epidemiology and clinical management of inhaled nitrite abuse. Pharmacotherapy, 24(1), 69-78. 
Royo-Isach, J., Magrané, M., Domingo, M., Cortés. B. (2004). La «keta» (ketamine): del fármaco a la droga de abuso. Clínica biopsicosocial del consumidor y algunas propuestas terapéuticas. Atención Primaria, 34(3), 147-51.

Saint-Martin, P., Bouyssy, M., O'Byrne, P. (2007). Analysis of 756 cases of sexual assault in Tours (France): medico-legal findings and judicial outcomes. Medicine, Science, and the Law, 47, 315-324.

Saint-Martin, P., Furet, Y., O'Byrne, P., Bouyssy, M., Paintaud, G., Autret-Leca, E. (2006). La soumission chimique: une revue de la littérature. Thérapie, 61,145-50.

Schwartz, R., Milteer, R., LeBeau, M. (2000). Drug-facilitated sexual assault (date rape). Southern Medical Journal, 93, 558-561.

Shapland, J. (1990) The Victims Movement in Europe. Victims of Crime. Problems, policies and Programs. Ed. R. Davis, A. J. Lurigio, W. G. Slogan, Sage. London.

Shbair, M. K., Lhermitte, M. (2010) Drug-facilitated crimes: Definitions, prevalence, difficulties and recommendations. A review. Annales Pharmaceutiques Françaises, 2010; 68 (3), 136-47.

Slaughter, L. (2000) Involvement of drugs involved in sexual assault. Journal of Reproductive Medicine, 45, 425-430.

So, D. W., Wong, F. Y., DeLeon, J. M. (2005). Sex, HIV, and substance use among Asian American college students. AIDS Education and Prevention, 17 (5), 457-468.

Sumnall, H. R., Beynon, C. M., Conchie, S. M., Riley, S. C., Cole, J. C. (2007). An investigation of the subjective experiences of sex after alcohol or drug intoxication. Journal of Psychopharmacology, 21, 527-537.

Sumnall, H. R., Cole, J. C., Jerome, L. (2006). The varieties of ecstatic experience: an exploration of the subjective experiences of ecstasy. Journal of Psychopharmacology, 20, 670-682.

Trullàs, J. C., Nogué, S., Miró, O., Munné, P. (2003). Uso criminal de psicofármacos. A propósito de un brote de 4 casos. Medicina Clínica (Barc), 121, 79.

Vega, P. (2012). Instrucciones de actuación en casos de agresión sexual con sospecha de intoxicación. Madrid: Ministerio de Justicia; 2012 [consultado 16 Nov 2014]. Disponible en: http://institutodetoxicologia.justicia.es

Xifró, A., Barbería, E., Pujol, A. (2014). Sumisión química con finalidad sexual en el laboratorio forense: datos de España. Revista Española de Medicina Legal, 40(1),1-3.

Xifró, A., Barbería, E., Pujol, A., Arroyo, A., Bertomeu, A., Montero, F. (2013). Sumisión química: guía de actuación médico-forense. Revista Española de Medicina Legal, 39(1), 32-36.

Xifró, A., Barbería, E., Pujol, A., Barbería, E., Arroyo, A., Bertomeu, A., Montero, F., Medallo, J. (2015). Estudio prospectivo de la sumisión química con finalidad sexual en Barcelona. Medicina Clínica, 144 (9), 403-409.

Zule, W. A., Desmond, D. P. (1999). An ethnographic comparison of HIV risk behaviours among heroin and methamphetamine injectors. American Journal of Drug and Alcohol, $25,1-23$. 